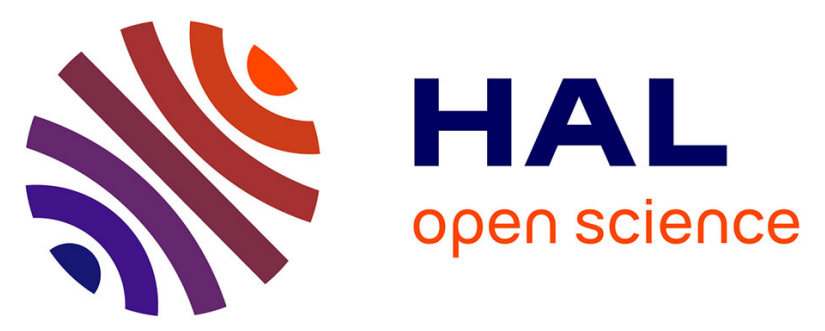

\title{
Prevalence and molecular characterization of avian infectious bronchitis virus in poultry flocks in Morocco from 2010 to 2014 and first detection of Italy 02 in Africa
}

Siham Fellahi, Mariette Ducatez, Mehdi El Harrak, Jean-Luc Guerin, Nadia Touil, Ghizlane Sebbar, El Arbi Bouaiti, Khadija Khataby, My Mustapha Ennaji, Mohammed El-Houadfi

\section{- To cite this version:}

Siham Fellahi, Mariette Ducatez, Mehdi El Harrak, Jean-Luc Guerin, Nadia Touil, et al.. Prevalence and molecular characterization of avian infectious bronchitis virus in poultry flocks in Morocco from 2010 to 2014 and first detection of Italy 02 in Africa. Avian Pathology, 2015, 44 (4), pp.287-295. 10.1080/03079457.2015.1044422 . hal-02632362

\section{HAL Id: hal-02632362 https://hal.inrae.fr/hal-02632362}

Submitted on 27 May 2020

HAL is a multi-disciplinary open access archive for the deposit and dissemination of scientific research documents, whether they are published or not. The documents may come from teaching and research institutions in France or abroad, or from public or private research centers.
L'archive ouverte pluridisciplinaire HAL, est destinée au dépôt et à la diffusion de documents scientifiques de niveau recherche, publiés ou non, émanant des établissements d'enseignement et de recherche français ou étrangers, des laboratoires publics ou privés. 
Publisher: Taylor \& Francis \& Houghton Trust Ltd

Journal: Avian Pathology

DOI: http://dx.doi.org/10.1080/03079457.2015.1044422

CAVP-2014-0170.R2

Prevalence and molecular characterization of avian infectious

bronchitis virus in poultry flocks in Morocco from 2010 to 2014 and first detection of Italy 02 in Africa.

Siham Fellahi ${ }^{1,2,3}$, Mariette Ducatez ${ }^{4,5}$, Mehdi El Harrak², Jean Luc Guerin ${ }^{5,4}$, Nadia Touil ${ }^{6}$, Ghizlane Sebbar ${ }^{2}$, El arbi Bouaiti ${ }^{6}$, Khadija khataby ${ }^{3}$, My Mustapha Ennaji ${ }^{3+}$ and Mohammed El Houadfi ${ }^{1+*}$.

${ }^{+}$Share equal contribution

${ }^{1}$ Unité de Pathologie Aviaire, Département de Pathologie et Santé Publique Vétérinaire, Institut Agronomique et Vétérinaire Hassan II, Rabat, Morocco, ${ }^{2}$ Société de Produits biologiques et pharmaceutiques vétérinaires, Rabat, Morocco, ${ }^{3}$ Laboratoire de Virologie, Microbiologie et Qualité/ETB- Faculté des Sciences et Techniques, Mohammedia, Université Hassan II-Casablanca, Mohammedia, Morocco, ${ }^{4}$ INRA UMR 1225 IHAP, F-31076, Toulouse, France, ${ }^{5}$ Université de Toulouse, INP, ENVT, UMR 1225 IHAP, F-31076, Toulouse, France and ${ }^{6}$ Ecole Royale du Service de Santé Militaire, Rabat, Morocco .

Running title: Detection of IBV Italy 02 in Morocco. 


\section{* Corresponding author:}

Tel: +212661157942 Fax: + 212537775845

E-mail: elhouadfimohammed@yahoo.fr

\section{Abstract}

The aim of this study was to investigate the prevalence and diversity of infectious bronchitis virus (IBV) genotypes in poultry flocks in 16 areas of Morocco between 2010 and 2014. A total of 360 flocks suspected of being infected by IBV were screened for the FBV $N$ gene using real time RT-PCR. Flocks were classified into four groups according to their IBV vaccination programme. Group 1 contained unvaccinated birds. Group 2, received a single application of live H120 vaccine. Groups 3 and 4 birds received one or two booster vaccination(s) respectively, mostly using the H120 vaccine. The real time RT-PCR results showed that $51.7 \%$ of the flocks were positive for the IBV genome with geographical disparities.

Molecular characterization of IBV was performed on 50 RT-PCR positive samples by partially sequencing the S1 gene, including the hypervariable regions (nucleotides 705-1097). Two predominant genotypes were detected, with the Massachusetts type dominating (66\%), among which $25 \%$ of the samples were identical to the H120 vaccine. The second most common genotype (present in $32 \%$ of the flocks) was surprisingly Italy 02 , revealing the first detection of this genotype in Morocco and also in Africa. 793B, the predominant genotype in the late 1990s in Morocco, was only detected in one occasion and was identical to the 4/91 vaccine strain. This study highlights the high prevalence of IBV in poultry farms in Morocco and confirms its continuous dynamic changes and evolution. 


\section{Introduction}

Infectious bronchitis (IB) is an acute and highly contagious viral disease affecting chickens of all ages, causing respiratory distress, nephritis, reduction in egg production and quality and increasing mortality rate. The disease is probably endemic in all regions where poultry are reared intensively. The causative agent is infectious bronchitis virus (IBV) belonging to the Gammacoronaviruses within the Coronaviridae family (Cavanagh, 2007). IBV has a singlestranded, positive sense RNA genome (Boursnell et al., 1987), which encodes three major structural proteins, the nucleocapsid protein $(\mathrm{N})$, the membrane protein $(\mathrm{M})$ and the spike glycoprotein (S) which is post-translationally cleaved into two subunits S1 and S2 (Cavanagh, 1983a, 1983b).

A large number of IBV serotypes and variants have been described worldwide (De Wit et al., 2011). Many of them do not completely cross-protect (Gelb et al., 1991; Cook et al., 2012). In North Africa, most of the information on IBV comes from Egypt, Morocco and Tunisia, where both indigenous and classical IBV variants appear to be present (De Wit et al., 2011). In Western Africa, a high prevalence (26\%) of IBV in poultry was detected by reverse transcriptase-polymerase chain reaction (RT-PCR) and a novel IBV variant 'IBADAN' has been described (Ducatez et al,, 2009).

In Morocco, the first isolation and characterization of IBV from poultry flocks was reported by El-Houadfi \& Jones (1985). Five isolates designated D, E, F, H and M were related serologically to the Massachusetts (Mass) serotype, while a new genotype, G strain was reported to differ from the Mass serotype and others European serotypes known at that time. The authors demonstrated under experimental conditions that Mass vaccines provided poor protection against the G strain (EL Houadfi et al., 1986). Interestingly, S1 sequence data 
have shown that IBV G and 4/91 strains are very closely related, probably sharing a common origin (Jones et al., 2004).

In 2004, a study investigated the relationships between IBV and outbreaks of nephropathogenic disease observed in broiler flocks in Morocco between 1996 and 2000 (Alarabi, 2004). Three different groups of IBV strains were identified using RT-PCR coupled with restriction fragment length polymorphism (RFLP) and isolates were classified into 3 groups. Isolates of group I were identified as Mass, the other IBV groups (group II and group III) were different from Mass types. The isolate 12/97, representative of group II, was found to cause severe kidney lesions and high mortality. Cross protection studies have shown that dual vaccination using the H120 and 4/91 vaccines at 1 day-old and 14 days of age respectively provided better protection against isolate 12/97 in comparison to single vaccination with $\mathrm{H} 120$ or 4/91. In addition, this strain was very closely related to the Moroccan G strain (Alarabi, 2004; EL Houadfi et al., 2004). E1 Bouqdaoui et al. (2005), while studying nephropathogenic IBV, identified five genotypes, three of which differed from vaccine strains, using RT-PCR and RFLP techniques.

Since 2005, several IBV outbreaks have been suspected to be present in poultry flocks in different regions of Morocco, despite the use of H120 and 4/91 vaccines (EL Houadfi, personal communication). The first goal of the present study was to investigate the prevalence of IBV infection in Moroccan poultry flocks, in various geographic regions over a four year period (2010-2014) where different vaccination strategies had been applied. The second objective was to identify the IBV genotypes circulating in the country and their importance and frequency in the field. 


\section{Materials and Methods}

Sampling scheme. Sixteen distinct Moroccan geographical areas were selected for this study (Table 1). A sampling scheme based on Probability Proportional to Size (PPS Sampling) was adopted. To take into account the possible importance of the larger units in the poultry flocks population, regions were selected with the probability proportional to geographical area. The following formula was used to calculate the sample size for estimating a given proportion with a $5 \%$ error margin (e):

$$
\begin{aligned}
& \qquad n=\frac{(1,96)^{2} p(1-p)}{e^{2}+\frac{(1,96)^{2} p(1-p)}{N}} \\
& \mathrm{n}=\text { Sampled units (sample size }=360) \\
& \mathrm{p}=\text { theoretical proportion (about } 44 \%) \\
& \mathrm{e}=5 \% \text { error margin }(95 \% \text { confidence level) } \\
& \mathrm{N}=\text { Existing broiler production units (Population size }=6407)
\end{aligned}
$$

A total of 360 flocks (328 broilers, 21 layers and 11 breeders) were sampled and their origins are shown in Table 1. Alr chickens experienced one or more of the following clinical signs or lesions: respiratory distress, nephritis, tracheitis, airsacculitis and, in the case of layers or breeders, drops in egg production and poor egg quality. Information on sampled cases related to age, mortality, clinical symptoms and postmortem lesions were recorded.

Vaccination protocols were given particular attention, especially day of vaccination, number of vaccinations and vaccine strains used. Indeed in Morocco, vaccine strains commercially available are of the Mass type (H120, Ma5 and modified Massachusetts strains), 793B type (4/91 and CR88) and since 2013 Arkansas type. However, because of its low price, $\mathrm{H} 120$ is the most common used vaccine in broiler chickens. 
Treatment of samples. Tracheal swabs, kidney, trachea and lung tissues were collected from flocks suspected of being infected by IBV. They were immediately placed on ice in sterile transport minimum essential medium (MEM) containing 5\% antibiotics $(20,000 \mathrm{IU} / \mathrm{ml}$ penicillin, 10,000 $\mu \mathrm{g} / \mathrm{ml}$ streptomycin, and $5000 \mu \mathrm{g} / \mathrm{ml}$ kanamycin) and sent to BIOPHARMA laboratory where they were immediately stored at $-80^{\circ} \mathrm{C}$ until analyzed. After thawing, each sample was homogenized with Dulbecco's modified Eagle's medium (DMEM). Tissue suspensions were centrifuged at $8000 \mathrm{~g}$ for $20 \mathrm{~min}$ at $4^{\circ} \mathrm{C}$. Then, $500 \mu 1$ of supernatant was clarified at $12000 \mathrm{~g}$ for $1 \mathrm{~min}$ and immediately processed.

RNA Extraction. Five samples from each case were pooled. Viral RNA was extracted from $50 \mu 1$ of the field specimens using the MagMaxTM-96 AI/ND viral RNA isolation kit (Applied Biosystem/Ambion, Austin TX, USA) according to the manufacturer's instructions. Each sample of extracted RNA was recovered from the plate and subjected to reverse transcriptase RT-PCR amplification.

One step real time RT-PCR for N gene detection. The oligonucleotides and the probe described by Rosie et al. (2010) are located in the conserved $\mathrm{N}$ gene, at nucleotide position 741-1077 of the Mass H120 strain (GenBank accession no. AM260960). Negative controls $\left(\mathrm{H}_{2} \mathrm{O}\right)$ and Newcastle Disease Virus, (NDV strain HB1) were included. A one step RT-PCR was carried out using Invitrogen kit (SuperScript ${ }^{\circledR}$ III Platinum, Life Technologies, USA). The reaction volume contained $12.5 \mu 12 \times \mathrm{RT}$-PCR buffer mix, $0.5 \mu 1 \mathrm{MgSO}_{4}(50 \mathrm{mM}), 0.5 \mu 1$ Rox $(25 \mathrm{mM}), 4.75 \mu 1$ nuclease free water, $0.5 \mu \mathrm{lM}-\mathrm{MULV}$ reverse transcriptase enzyme (200 $\mathrm{U}), 0.5 \mu \mathrm{l}$ primers to a final concentration of $10 \mu \mathrm{M}, 0.25 \mu \mathrm{l}$ probe to a final concentration of $10 \mu \mathrm{M}$ and $5 \mu 1 \mathrm{RNA}$ template. The reaction was carried out in StepOneTM Plus real-time PCR system (Smart cycler Cepheid, USA) at $50^{\circ} \mathrm{C}$ for $15 \mathrm{~min}, 95^{\circ} \mathrm{C}$ for $5 \mathrm{~min}$, and 40 cycles 
of $95^{\circ} \mathrm{C}$ for $15 \mathrm{~s}$ and $60^{\circ} \mathrm{C}$ for $45 \mathrm{~s}$. Amplifications were recorded, analyzed, and the threshold cycle $(\mathrm{Ct})$ determined with the StepOne software (Smart Cycler).

Nested RT-PCR for S1 gene amplification. Fifty samples positive by RT-PCR were selected for further study in order to include all epidemiological criteria: vaccination status, severity of clinical signs, years of detection, and to cover all regions of Morocco. However, all 6 positive samples of group 4 (3 times vaccinated) were sequenced (Table 1), in order to understand better the vaccine failures. The RT-PCR products were subjected to S1 gene nested RT-PCR amplification, using the primers and protocol described by Jones et al. (2005) and Worthington et al. (2008).

DNA sequencing. Fifty selected RT-PCR products (393bp) generated with the nested RTPCR and containing a region known to vary between strains were purified using the Gene Clean Kit (ExoSAP-IT), according to the manufacturer's recommendations and sequenced using the primers (SX3+ and SX4-). Determination of the nucleotide sequences was performed using the BigDye(R) Terminator v1.1 Cycle Sequencing Kit and the second purification was performed using the Big Dye X terminator Purification Kit.

Nucleotide sequence analyses. Assembly and analysis of sequence data were conducted using the BioEdit Software version 5.0.9 (Hall, 1999).Phylogenetic analysis and tree construction for the S1 glycoprotein were generated using the maximum likelihood (ML) method with 1,000 bootstrap replicates with MEGA software Version 5.05 program (Tamura et al., 2011), and bootstrap values above 50 were labeled on major tree branches for reference. 
As the primers used in this study do not differentiate between vaccine and field viruses of the same genotype, we compared the sequences of the viruses detected as Mass and 793B genotypes with those of the vaccine types published in NCBI (H120: accession number M21970 ; 4/91: accession number AF093793).

Statistical analyses. Statistical Package for the Social Sciences (SPSS) version 13 was used for statistical analyses. Descriptive statistics including percentages, means and frequency distribution, were calculated for each of the variables. The Chi-square test was used to investigate the correlations of IBV detection between regions and between groups. The frequency of IBV infection in different groups was calculated using logistic regression analysis. A p-value of less than 0.05 was considered significantly different.

Genbank accession numbers. The partial S1 gene sequences of the viruses analyzed in this study were deposited in GenBank with accession numbers shown in Table 2.

Nucleotide and amino acid deduced $S 1$ sequences of reference IBV strains included in the comparisons were available in GenBank under the following accession numbers: Ark99 (M99482); 4/91 (AF093793); Beaudette (X02342); M41 (X04722); H120 (M21970); Ma5 (AY561713); D1466 (M21971); Moroccan-G/83 (EU914938); QX (AF193423); D274 (X15832); NGA/A116E7/2006 (FN182257); Q1 (AF286302); Gray (L14069); Spain/00/336 (DQ386098); Spain/99/327 (DQ386097); Spain/05/866 (DQ386102); Spain/04/221 (DQ386103); Italy-02 (AJ457137); UK L-633/04 (DQ901376); Spain/98/315 (DQ386095); Spain/92/35 (DQ386091); Spain/95/193 (DQ386093); Spain/04/22(DQ386100). 


\section{Results}

Field IBV vaccination. In this study, several different vaccination protocols were recorded (Table 1). 87 flocks out of 360 (24.2\%) did not receive any IBV vaccine (group I ). 205 flocks $(56.9 \%)$ received one vaccination with $\mathrm{H} 120$ between one and seven days of age (group 2 ). 38 flocks (10.6\%) were vaccinated twice, at one week of age with H120 followed by a booster vaccination between two and three weeks of age (group 3 ). 30 flocks (8.3\%) received three vaccinations at 1,2 , and 3 weeks of age (group 4). Among the 263 vaccinated flocks studied, only 13 flocks had been boosted with IB 4/91 vaccine. The remaining flocks were boosted with H120.

Virus prevalence in different vaccination status. The number of selected farms based on the statistical (SPSS) sampling method in southern, western, eastern and central regions of Morocco is shown in Table 1. Among 360 flocks sampled, 273 had been vaccinated against IBV (75.8\%). IBV detections occurred in broiler flocks aged between 19 and 45 days and in commercial layer flocks aged between 17 and 51 weeks, distributed in all areas of Morocco. Among these flocks, $62.5 \%$ showed respiratory signs.

The real time RT-PCR results revealed that $51.7 \%(186 / 360)$ of the suspected infected IBV flocks were indeed IBV-positive. IBV was detected in all regions. In group 1 (unvaccinated birds), the relative prevalence of IBV infection reached $66.7 \%$, followed by $54 \%$ in group 2 (1 vaccination), 21\% in group 3 (2 vaccinations) and 20\% in group 4 (3 vaccinations). The effect of vaccination in different groups was investigated. The odd ratios obtained between group 1 and group 2 was 1.257 (95\% CI, 0.826-1.913), with no statistically significant effect of vaccination ( $p$ : 0.286). In groups 3 and 4 , the risk of infection with IBV was reduced by $75 \%$ and $80 \%$, respectively, and the odd ratios were 0.281 (95\% CI, 0.123 - 
0.644, ( $p$ 0.003) and 0.208 (95\% CI, 0.083-0.523, $p<0.000001)$. Despite the difference of IBV prevalence between regions, no statistically significant differences were found.

IBV genotypes. Among the 186 samples positive for IBV by real time RT-PCR (51.7\%), 50 samples were sequenced for the S1 gene using both primers (SX3+ and SX4-) described previously by Jones et al. (2005). Partial nucleotide sequences of the S1 genes (393 bp) of the Moroccan IB viruses were compared with published IBV sequences using BLAST search within the EMBL/GenBank database (Table 2). During the four years of this study, the predominant genotype detected was Mass (66\%), followed by Italy02 (32\%) and only one sample belonged to the 793B genotype (2\%). Among the two genotypes, the Mass genotype was dominant between 2011 and 2013, while Italy 02 was constantly present during the four years of the study.

In unvaccinated flocks both Italy 02 and Mass wild type (differentiated from H120 vaccine by nucleotide alignment) were found to be more or less equally distributed (found at prevalence of $55 \%$ and $45 \%$, respectively). In vaccinated flocks, Mass wild type (Wt) and Italy 02 were detected in all groups $(2,3$, and 4$)$ but with different frequencies: Mass Wt clearly dominated in groups 2 and 4 (Figure 1).

The distribution of the IBV genotypes between regions demonstrated that the Mass genotype is ubiquitous and was found in almost all regions. However Italy 02 was concentrated more in the centre and north regions of Morocco (Figure 2). The amino acid sequences of the $\mathrm{S} 1$ gene of the $50 \mathrm{IBVs}$ in different regions and different years, compared to the reference strains are represented in Figure 3. Phylogenetic analyses confirmed that Moroccan viruses are grouped into three genotypes: Mass, Italy 02 and 793B. The Moroccan IBV field viruses had amino acid sequence similarity variation of $42.4 \%$ between IBV/Morocco/23/2013 and IBV/Morocco/16/2013 and 100\% between IBV/Morocco/39/2010 
and IBV/Morocco/05/2010. In comparison with 23 reference strains, they had amino acid sequence similarity variation between 44.4\% (IBV/Morocco/27/2012 and D1466) and 98.4\% (between IBV/Morocco/05/2010 and H120) (data not shown).

Nucleotide sequence alignments and comparison revealed that $25 \%$ of the field viruses had $100 \%$ sequence identity with the commercial H120 live vaccine (IBV/43/2013 to IBV/28/2012), while $75 \%$ were different from the vaccine strain and grouped in 2 clusters (Figure 3). The first and main cluster (with $96 \%$ of the non-vaccine Mass viruses) was detected in all regions of the country (IBV/40/2013 to IBV/11/2012), while the second cluster was observed only in the southern regions of Morocco and included IBV/48/2013 and IBV/23/2013, which were detected in 2013 (Figure 3). In this study, the 793B genotype, a virus associated with nephritis, which predominated in the 1980s and 1990s in Morocco (Jones \& EL Houadfi, 1985, Alarabi, 2004; El Bouqdaoui et al., 2005) was detected only on one occasion. This virus was found to share $100 \%$ nucleotide identity to the $4 / 91$ vaccine strain (accession number AJ457137).

\section{Discussion}

In this study, a comprehensive survey of IBV throughout Morocco was performed on 360 flocks showing clinical signs of respiratory infection, kidney diseases, or, in layers and breeders, loss of egg production and quality. IBV infection was found to be a common disease in poultry farms and occurred in almost all regions. IBV RNA was detected in 51.7\% of the flocks tested. This prevalence is relatively similar (59\%) to that found in Western Europe (Worthington et al., 2008). This high frequency found in Morocco and in Western Europe might be due to the fact that flocks sampled were experiencing clinical signs and suspected to be infected with IBV. However in Morocco, many factors such as the lack of an 
appropriate vaccination programme and application, or lack of biosecurity, for example in multi-age rearing systems which are still wildly used. The differences in IBV prevalence found among groups 2, 3, and 4, illustrated that the more often birds were vaccinated the fewer were infected. Groups 3 and 4, which received respectively one and two booster vaccinations, were better protected than flocks receiving a single vaccination. Similar findings have been reported by Jackwood et al. (2009). Those authors found that two vaccinations against IBV, a prime at 1 day of age and a booster between 14-18 days of age, were necessary to induce a protective local antibody response in the upper respiratory tract. Ignjatovic \& Galli (1995) also reported that chicks vaccinated at 14 days of age had significantly higher titres of S1 and S2 antibodies than chicks vaccinated at either 1 or 7 days of age. Controlling IB only by increasing the frequency of vaccination does not always work, especially when field strains are antigenically distinct from the applied vaccines strains. This situation is well illustrated in this study, which shows that IBV RNA was detected in $20 \%$ of the flocks in group 4, despite the use of three applications of H120 vaccine. This suggests that other genotypes, such as Italy 02 genotype (IBV09 and IBV38 specimens from group 4), or probably wild type Mass genotype (IBV11, 35, 36 and 39 from group 4) [Table 2] are circulating in Morocco, as has been shown previously (El Houadfi et al., 1986; Alarabi, 2004; E1 Bouqdaoui et al., 2005). In North Africa, IBV variants have been poorly studied. However, Bourogâa et al. (2009b) identified new IBV isolates for the first time in Tunisia, which co-circulated along with the Mass type, causing severe clinical diseases and high economic losses to the poultry industry (Bourogâa et al., 2009a, 2009b). In Egypt, isolates related to Mass, D3128, D274, D-08880, 4/91 and the novel genotype; Egypt/Beni-Suef/01 were characterized (Abdel-Moneim et al., 2006; Mahmood et al., 2011). Indeed, new strains/genotypes of IBV are in continuous emergence in Egypt (Abdel-Moneim, 2012). 
During the last decade, two new economically important field types of IBV named QX and Italy 02 genotypes, were isolated in domestic poultry in Europe (Jones et al., 2005; Bochkov et al., 2007; Dolz et al., 2007; Valastro et al., 2010; Krapez et al., 2011; Ganapathy et al., 2012), China (Beato et al., 2005; Zhao et al., 2014 ) and in the Middle East (Amin et al., 2012). However, in Africa only QX viruses have so far been detected, in Zimbabwe (Toffan et al., 2011).

The survey of IBV genotypes in Western Europe using universal primers for IBV, followed by sequencing of positive PCR products for the S1 spike gene, revealed that 793B was the most common type detected, followed by Mass, including different vaccine strains. That study revealed the emergence of Italy 02 genotypes in all countries from which samples were received, whereas QX was the fourth most commongenotype, predominant in all countries except the United Kingdom and Spain (Worthington et al., 2008).

Variation in the IBV S1 gene is very often used to distinguish between different IBV genotypes. The generation of genetic variants is thought to be the result of very few amino acid changes in the spike (S) glycoprotein of IBV (Kant et al., 1992; Cavanagh et al., 1992; Wang, 2000; Dolz et al., 2006). The S1 primer set was used previously for characterizing field samples in Western Europe and was shown to detect a wide range of IBV genotypes (Jones et al., 2005; Worthington et al., 2008), which brings confidence in our results, although the possibility of strains harbouring mismatches at primer locations cannot be ruled out.

The results of our study show that the most frequently detected IBV genotypes were Mass and for the first time in Africa, Italy 02 type. The Mass genotype was predominant with a prevalence of $66 \%$. This result is not surprising as Mass vaccines have been used in Morocco since 1960. Previous results published in Morocco showed that the Mass IBV type was the first isolated in Morocco in the 1980s (EL Houadfi et al., 1986). The authors then 
characterized six isolates of IBV, among which five isolates were related serologically to the Mass serotype. The analysis of the nucleotide sequences of the Mass genotype over the S1 section of the spike gene indicated that $25 \%$ of the Mass viruses were identical to live H120 vaccine. Again, this was expected considering the extensive use of H120 vaccines. Cavanagh et al. (1999) reported that when Mass type IB vaccines were applied at 1 day-old in the hatchery, vaccine virus could later be detected in all broiler flocks tested by RT-PCR using tracheal swabs, with maximal amounts during the first week of life. Naqi et al. (2003) using RT-PCR and sequencing, also demonstrated the persistence of vaccine virus for many weeks after administration. Therefore, it was not surprising that we detected vaccine-strains in this survey.

The remaining $75 \%$ of detected Mass viruses indicated that wt Mass viruses are widespread in Morocco and might cause significant losses to the poultry industry. Further investigations related to cross protection and pathogenicity of the two Mass variants detected in the country are needed, especially as Callison et al. (2001) have demonstrated that nucleotide sequences of the whole S1 spike gene of the 4/91 vaccine strain and pathogenic virus of 793B only differ by $0.6 \%$. In this way we could perhaps determine whether we indeed detect wild Mass viruses or whether they might have been vaccine-derived variants.

The second most frequently detected genotype was Italy 02 . This is the first study in which Italy 02 types has been detected in Morocco and in Africa. The geographical proximity and close transboundary of Morocco and Europe may explain in part the dominance of this genotype in the north and central regions of Morocco. Spain is also the only country exporting breeder chicks to Morocco (ONSSA; 2014). The Italy 02 genotype was originally isolated in Italy in 1999 (Bochkov et al., 2007) and it has been reported in Spain since 1997 (Dolz et al., 2006). Dolz et al. (2008, 2012) investigated IBV variants in Spain and reported that Italy 02 is the predominant genotype in that country. This genotype was detected 
throughout Western Europe (Worthington et al., 2008) and in Russia (Bochkov et al., 2006). Recently, Dolz et al., (2014) reported that Italy 02 prevalence in Western European countries decreased shortly after its emergence, however, Spain was the only country where this genotype was predominant up to 2011, before being replaced by QX in 2012 and by 4/91 since 2013 (Dolz et al., 2014). In Morocco, the Italy 02 genotype was detected for the first time in 2010 and its frequency seemed to increase so that it become the most common IBV genotype in 2014. A retrospective study on Moroccan isolates collected since 1982 is ongoing to determine when Italy 02 was introduced to Morocco.

Before starting this study we were expecting to detect the QX genotype because of its widespread distribution in many countries, but the sequencing result of 50 IBV did not show any QX-like genotype. Interestingly, it was surprising to find that the 793B genotype had almost disappeared from the country, while it was predominant in the 1980s and 1990s (E1 Houadfi et al., 1986; Alarabi, 2004; El Bouqdaoui et al., 2005). It would thus be worth trying to understand what might be the main cause of 793B decline in Morocco. This could probably be related to the intensive use of $4 / 91$ vaccine for preventing the outbreaks of renal disease, which have affected the country since 1995, and against which it has been found that 4/91 was very protective in combination with H120 (Alarabi, 2004; EL Houadfi et al., 2004). In Spain, Dolz et al. (2008) suggested that the emergence of Italy 02 displaced 793B genotype, which is also possibly the case in Morocco. This phenomenon illustrates the continuous evolution and the dynamic changes of IBV, which complicate the establishment of vaccine strategies to control it. These strategies need to be adapted continuously to the field situation in Morocco.

\section{Acknowledgement}

This work was supported by the Agronomy and Veterinary Institute Hassan II, Ministry of Higher Education of Morocco and the Society of Biopharma. 


\section{References}

Abdel-Moneim, A.S., El-Kady, M.F., Ladman, B.S. \& Gelb, J. Jr. (2006).S1 gene sequence analysis of a nephropathogenic strain of avian infectious bronchitis virus in Egypt. Virology Journal, 20, 78.

Abdel-Moneim, A.S., Afifi, M.A. \& El-Kady, M.F. (2012).Emergence of a novel genotype of avian infectious bronchitis virus in Egypt. Archive of Virology, 157, 2453-2457.

Alarabi, M.A.H. (2004). PhD thesis. A field study of kidney disease among the broiler flocks in Morocco and its relationship with infectious bronchitis virus. Agronomy and Veterinary Institute Hassan II.

Amin, O.G., Valastro, V., Salviato, A., Drago, A., Cattoli, G.\& Monne, I. (2012). Circulation of QX-like infectious bronchitis virus in the Middle East. Veterinary Record, 171, 530.

Beato, M.S., De Battisti, C., Terregino, C., Drago, A., Capua, I. \& Ortali, G. (2005).Evidence of circulation of a Chinese strain of infectious bronchitis virus (QX IBV) in Italy. Veterinary Record, 156, 720

Bochkov, Y.A., Batchenko, G.V., Shcherbakova, L.O., Borisov, A.V. \& Drygin, V.V. (2006).Molecular epizootiology of avian infectious bronchitis in Russia. Avian Pathology, 35, 379-393.

Bochkov, Y.A., Tosi, G., Massi. P. \&Drygin, V.V. (2007). Phylogenetic analysis of partial S1 and $\mathrm{N}$ gene sequences of infectious bronchitis virus isolates from Italy revealed genetic diversity and recombination. Virus Genes, 1, 65-71.

Boursnell, M. E., Brown, T. D., Foulds, I. J., Green, P. F., Tomley, F. M. \& Binns, M. M. (1987).Completion of the sequence of the genome of the coronavirus avian infectious bronchitis virus. Journal of General Virology, 68, 57-77. 
Bourogâa, H., Miled, K., Larbi, I., Nsiri, J., Gribâa, L., El Behi, I., Benrhouma, W., Allagui, F., Sassi, H. \&Ghram, A. (2009a). La bronchite infectieuse aviaire en Tunisie: séroprévalence, pathogenicité et étude de compatibilité vaccins-isolats. Archives de l'Institut Pasteur de Tunis, 86, 1-4.

Bourogâa, H., Miled, K., Gribâa, L., El Behi, I. \& Ghram, A. (2009b). Characterization of new variants of avian infectious bronchitis virus in Tunisia. Avian Diseases, 53, 426433.

Callison, S.A., Jackwood, M.W. \& Hilt, D.A. (2001).Molecular characterization of infectious bronchitis virus isolates foreign to the United States and comparison with United States isolates. Avian Disease, 45, 492-499.

Cavanagh, D. (1983a). Coronavirus IBV: further evidence that the surface projections are associated with two glycopolypeptides. Journal of General Virology, 64, 1787-1791.

Cavanagh, D. (1983b). Coronavirus IBV: structural characterization of the spike protein. Journal of General Virology, 64, 2577-2583.

Cavanagh, D., Davis, P.J., Cook, J.K.A., Li, D., Kant, A. \& Koch, G. (1992).Location of the amino acid differences in the $\$ 1$ spike glycoprotein subunit of closely related serotypes of infectious bronchitis virus. Avian Pathology, 21, 33-43.

Cavanagh, D., Mawditt, K., Britton, P. \& Naylor, C.J. (1999). Longitudinal studies of infectious bronchitis virus and avian pneumovirus in broiler using type-specific polymerase chain reactions. Avian Pathology, 28, 593-605.

Cavanagh, D. (2007). Coronavirus avian infectious bronchitis virus. Veterinary Research, 38, 281-297.

Cook, J, K. A., Jackwood, M. \& Jones, R. C. (2012). The long view: 40 years of infectious bronchitis research. Avian Pathology, 41, 239-250. 
De Wit, J. J., Cook, J. K. A. \& Van der Heijden, H. M. (2011). Infectious bronchitis virus variants: a review of the history, current situation and control measures. Avian Pathology, 40, 223-235.

Dolz, R., Valle, R. \& Majo, N. (2014). Infectious bronchitis virus field epidemiology in Spain: still missing questions. In: E.F. Kaleta\& U. Heffels-Redmann (Eds.). Proceedings of the IIX International Symposium on Avian Corona- and Pneumovirus Infections (pp. 105-111). Rauischholzhausen, Germany.

Dolz, R., Pujols, J., Ordóñez, G., Porta, R. \& Majó, N. (2006).Antigenic and molecular characterization of isolates of the Italy 02 infectious bronchitis virus genotype. Avian Pathology, 35, 77-85.

Dolz, R., Pujols, J., Ordóñez, G., Porta, R. \& Majó, N. (2008).Molecular epidemiology and evolution of avian infectious bronchitis virus in Spain over a fourteen-year period. Virology, 374, 50-59.

Dolz, R., Vergara-Alert, J., Pérez, M., Pujols, J. \& Majó, N. (2012). New insights on infectious bronchitis virus pathogenesis: characterization of Italy 02 serotype in chicks and adult hens. Veterinary Microbiology, 156, 256-264.

Dolz, R., Pujols, J., Ordóñez, G., Porta, R.\& Majó, N. (2006). Antigenic and molecular characterization of isolates of the Italy 02 infectious bronchitis virus genotype. Avian Pathology, 35, 77-85.

Dücatez, M.F., Martin, A.M., Owoade, A.A., Olatoye, I.O., Alkali, B.R., Maikano, I., Snoeck, C.J., Sausy, A., Cordioli, P. \& Muller, C.P. (2009). Characterization of a new genotype and serotype of infectious bronchitis virus in Western Africa. Journal of General Virology, 90, 2679-2685. 
El Bouqdaoui, M., Mhand, R. A., Bouayoune, H. \& Ennaji, M. M. (2005).Genetic Grouping of Nephropathogenic Avian Infectious Bronchitis Virus Isolated in Morocco. International Journal of Poultry Science, 4, 721-727.

El-Houadfi, M. \& Jones, R. C. (1985). Isolation of avian infectious bronchitis viruses in Morocco including an enterotropic variant. Veterinary Record, 116, 445.

El-Houadfi, M., Jones, R.C., Cook, J.K. A. \& Ambali, A. G. (1986). The isolation and characterization of six avian infectious bronchitis viruses isolated in Morocco. Avian Pathology, 15, 93-105.

EL-Houadfi, M., ALArabi, M.A.H, Bakkali, L.K., EL Harrak, M., Bouzoubaa, K., Cook, J.K.A \& Jones, R.C. (2004). Pathogenicity, charachterization and protection studies of a nephropathogenic IBV isolate $12 / 97$ in Morocco. In E.F. Kaleta \& U. HeffelsRedmann (Eds.). Proceedings of the IV International Symposium on Avian Coronaand Pneumovirus Infections (pp. 93-104). Rauischholzhausen, Germany.

Ganapathy, K., Wilkins, M., Forrester, A., Lemiere, S., Cserep, T., McMullin, P. \& Jones, R.C (2012). QX-like infectious bronchitis virus isolated from cases of proventriculitis in commercial broilers in England. Veterinary Record, 171, 597.

Gelb, J. J., Wolff, J. B. \& Moran, C. A. (1991). Variant serotypes of infectious bronchitis virus isolated from commercial layer and broiler chickens. Avian Disease, 35, 82-87.

Hall, T.A. (1999). BioEdit: a user-friendly biological sequence alignment editor and analysis for Windows 95/98/NT. Nucleic Acids Symposium Series, 41, 95-98.

Ignjatovic, J. \& Galli, U. (1995).Immune responses to structural proteins of avian infectious bronchitis virus. Avian Pathology, 24, 313-332.

Jackwood, W.M., Deborah, A. H., Amber, W. M., Crystal, N. P., Enid, T. M. \& Susan, M. W. (2009).Infectious Bronchitis Virus Field Vaccination Coverage and Persistence of Arkansas-Type Viruses in Commercial Broilers. Avian Diseases, 53, 175-183. 
Jones, R. C., Savage, C. E., Naylor, C. J., Cook, J. K. A. \& El-Houadfi, M. A. (2004).

Possible North African progenitor of the major European infectious bronchitis variant (793B, 4/91, CR88).In: E. F. Kaleta \& U. Heffels-Redmann (Eds.). Proceedings of the IV International Symposium on Avian Corona- and Pneumovirus Infections (pp. 105111). Rauischholzhausen, Germany.

Patalla, P., Mondal, S. \& Liu, R. (2003). Establishment of persistent a avian infectious bronchitis virus infection in antibody-free and antibody-positive chickens. Avian Diseases, 47, 594-601.

Office National de Sécurité Sanitaire des Produits Alimentaires (ONSSA), Ministry of Agriculture and Fisheries, Morocco: Annual Report, 2014.

Tamura, K.P.D., Peterson, N., Stecher, G., Nei, M.,Kumar, S. (2011). MEGA5: molecular evolutionary genetics analysis using maximum likelihood, evolutionary distance, and maximum parsimony methods. Molecular Biology and Evolution, 28, 2731-2739.

Rosie, M., Ora, M., Ygal, F. \& Lubov, S. (2010). Development of a real-time TaqMan® RTPCR assay for the detection of infectious bronchitis virus in chickens, and comparison of RT-PCR and virus isolation. Journal of Virology Methods, 163, 190-194.

Toffan, A., Monne, I., Terregino, C., Cattoli, G., Hodobo, C.T., Gadaga, B., Makaya, P.V., Mdlongwa, E. \& Swiswa, S. (2011). QX-like infectious bronchitis virus in Africa. Veterinary Record, 169, 589.

Valastro, V., Monne, I., Fasolato, M., Cecchettin, K., Parker, D., Terregino, C. \& Cattoli, G. (2010).QX-type infectious bronchitis virus in commercial flocks in the UK. Veterinary Record, 167, 865-866.

Wang, C.H. \& Huang, Y.C. (2000).Relationship between serotypes and genotypes based on the hypervariable region of the $\mathrm{S} 1$ gene of infectious bronchitis virus. Archives of Virology, 145, 291-300. 
Worthington, K. J., Currie, R. J. W. \& Jones, R. C. (2008).A reverse transcriptase-

polymerase chain reaction survey of infectious bronchitis virus genotypes in Western Europe from 2002 to 2006. Avian Pathology, 37, 247-257.

Zhao, Y., Liu, X.Y., Cheng, J.L., Wu, Y.P. \& Zhang, G.Z. (2014).Molecular characterization of an infectious bronchitis virus strain isolated from northern China in 2012. Archives of Virology, 159, 3457-3461. 
Figure 1. Distribution of IBV genotypes detected in flocks in which IB H120 vaccine was applied once (V1), twice (V2) or three times (V3).

Mass Wt: Wild type of Massachusetts genotype; Mass V: Vaccine strain of Massachusetts genotype.

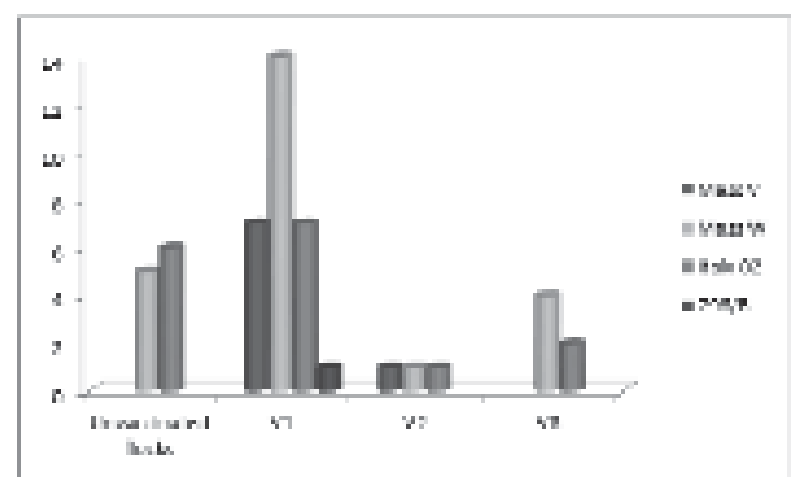


Figure 2. Map showing the distribution of IBV genotypes and the region of Morocco where they were detected.

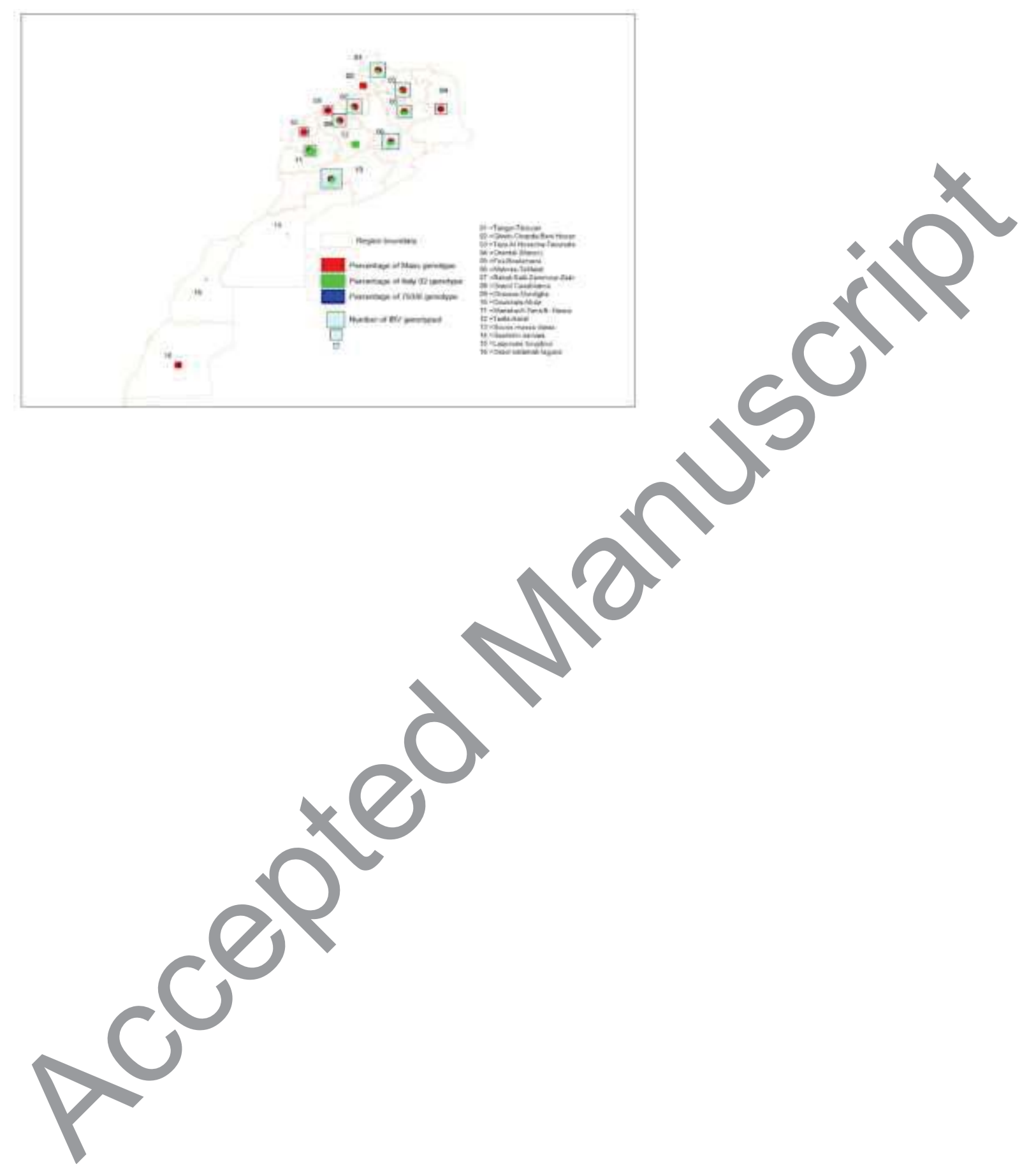


Figure 3. Phylogenetic tree (Maximum Likewood tree) of the S1 gene from 50 IBV viruses.

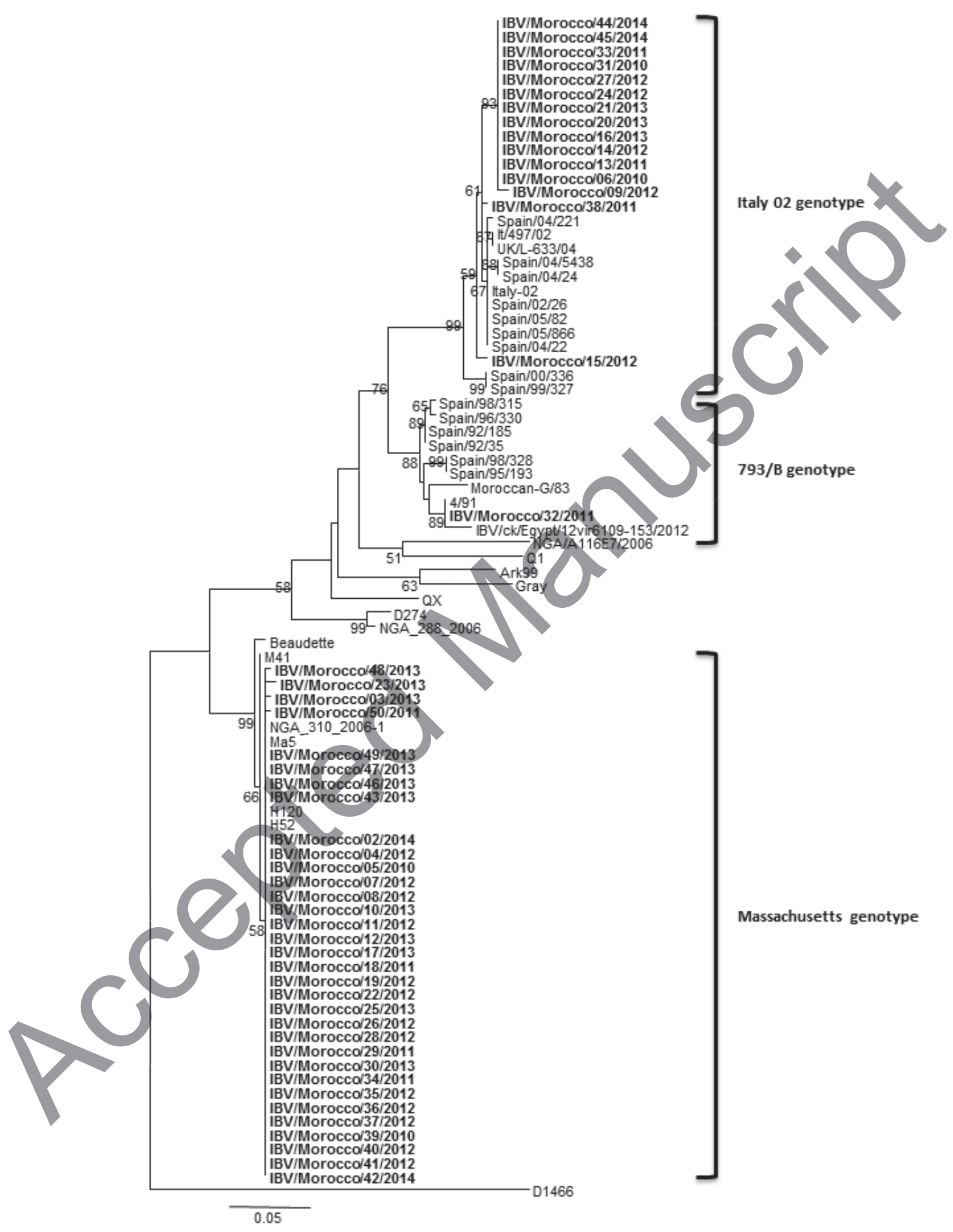


Table 1. Prevalence of Infectious Bronchitis infection in poultry chickens from 16 regions of Morocco.

\begin{tabular}{|c|c|c|c|c|c|c|}
\hline \multirow[t]{2}{*}{ Region } & \multirow[t]{2}{*}{ Locationa } & \multirow{2}{*}{$\begin{array}{l}\text { Unvaccinated } \\
\text { flocks } \\
\text { Group } 1^{\mathrm{b}}\end{array}$} & \multicolumn{3}{|c|}{ Vaccinated flocks } & \multirow[t]{2}{*}{ Total } \\
\hline & & & Group $2^{c}$ & Group 3d & $\begin{array}{c}\text { Group } \\
4 \mathrm{e}^{\mathrm{s}}\end{array}$ & \\
\hline Fès-Boulemane & $\mathrm{N}$ & $2 / 4(50)^{f}$ & $8 / 16(50)$ & $1 / 1(100)$ & $0 / 3(0)$ & $\begin{array}{l}11 / 24 \\
(45.8)\end{array}$ \\
\hline Casablanca & W & 0 & $6 / 8(75)$ & $0 / 1(0)$ & 0 & $6 / 9(66.7)$ \\
\hline $\begin{array}{l}\text { Marrakech- } \\
\text { Tensift- Haouz }\end{array}$ & C & $0 / 2(0)$ & $\begin{array}{c}4 / 12 \\
(33.3)\end{array}$ & $\begin{array}{l}4 / 13 \\
(30.7)\end{array}$ & $0 / 9(0)$ & $8 / 36(22.2)$ \\
\hline $\begin{array}{l}\text { Rabat-Salé- } \\
\text { Zemmour-Zaër }\end{array}$ & NW & $1 / 1(100)$ & $\begin{array}{l}14 / 22 \\
(63.6)\end{array}$ & $0 / 2(0)$ & $\begin{array}{c}1 / 1 \\
(100)\end{array}$ & $\begin{array}{l}15 / 26 \\
(57.7)\end{array}$ \\
\hline Doukkala-Abda & WC & $7 / 10(70)$ & $6 / 13(46)$ & 0/12 (0) & $0 / 4(0)$ & $\begin{array}{r}13 / 39 \\
(333)\end{array}$ \\
\hline $\begin{array}{l}\text { Meknès- } \\
\text { Tafilalet }\end{array}$ & NC & $7 / 12(58)$ & $\begin{array}{c}11 / 19 \\
(57)\end{array}$ & $(10$ & $1 / 3$ & $\begin{array}{l}20 / 35 \\
(57.1)\end{array}$ \\
\hline Tanger-Tétouan & NW & $5 / 7(71.4)$ & $\begin{array}{c}7 / 15 \\
(46.6)\end{array}$ & & (0) & $12 / 24(50)$ \\
\hline Tadla-Azilal & C & $1 / 1(100)$ & $\begin{array}{l}5 / 12 \\
(41.6)\end{array}$ & $\begin{array}{c}1 / 3 \\
(33.3)\end{array}$ & $3 / 5(60)$ & $\begin{array}{l}10 / 21 \\
(47.6)\end{array}$ \\
\hline $\begin{array}{l}\text { Gharb-Chrarda- } \\
\text { Ben Hssen }\end{array}$ & NW & $1 / 3(33.3)$ & & $0 / 1(0)$ & 0 & $4 / 15(26.7)$ \\
\hline Oriental & $\mathrm{E}$ & 11/15 (73.3) & 146 & 0 & 0 & $\begin{array}{l}13 / 19 \\
(68.4)\end{array}$ \\
\hline $\begin{array}{l}\text { Taza-Al } \\
\text { Hoceima- } \\
\text { Taounat }\end{array}$ & $\mathrm{N}$ & & $8(12.5)$ & 0 & 0 & $9 / 18(50)$ \\
\hline $\begin{array}{l}\text { Chaouia- } \\
\text { Ourdigha }\end{array}$ & NC & & $\begin{array}{l}11 / 23 \\
(47.8)\end{array}$ & $1 / 4(25)$ & 0 & $\begin{array}{l}19 / 36 \\
(54.3)\end{array}$ \\
\hline $\begin{array}{l}\text { Laâyoune- } \\
\text { Boujdour }\end{array}$ & $\mathrm{s}$ & & $0 / 1(0)$ & 0 & $\begin{array}{c}1 / 3 \\
(33.3)\end{array}$ & $1 / 4(25)$ \\
\hline $\begin{array}{l}\text { Souss massa } \\
\text { Daraa }\end{array}$ & & $(61.5)$ & $\begin{array}{l}37 / 41 \\
(90.2)\end{array}$ & 0 & 0 & $\begin{array}{l}45 / 54 \\
(81.8)\end{array}$ \\
\hline Guelmim Smara & & 0 & 0 & 0 & 0 & 0 \\
\hline $\begin{array}{l}\text { Oued Ed- } \\
\text { Dahab-Lagouir }\end{array}$ & & 0 & 0 & 0 & 0 & 0 \\
\hline & & $58 / 87(66.7 \%)$ & $\begin{array}{c}114 / 205 \\
(54 \%) \\
\end{array}$ & $\begin{array}{c}8 / 38 \\
(21 \%)\end{array}$ & $\begin{array}{c}6 / 30 \\
(20 \%) \\
\end{array}$ & $\begin{array}{l}186 / 360 \\
(51.7 \%)\end{array}$ \\
\hline
\end{tabular}

a Location of the regions in Morocco, N: Northern, W: Western, S: Southern, C: Central, E: Eastern. b Group 1 contained unvaccinated flocks.

${ }^{\circ}$ Group 2 one application of Mass $\mathrm{H} 120$ live vaccine.

${ }^{d}$ Group 3 two applications of Mass $\mathrm{H} 120$ live vaccine.

e Group 4 three applications of Mass H120 live vaccine.

${ }^{f}$ Number positive/ number examined (\%positive). 


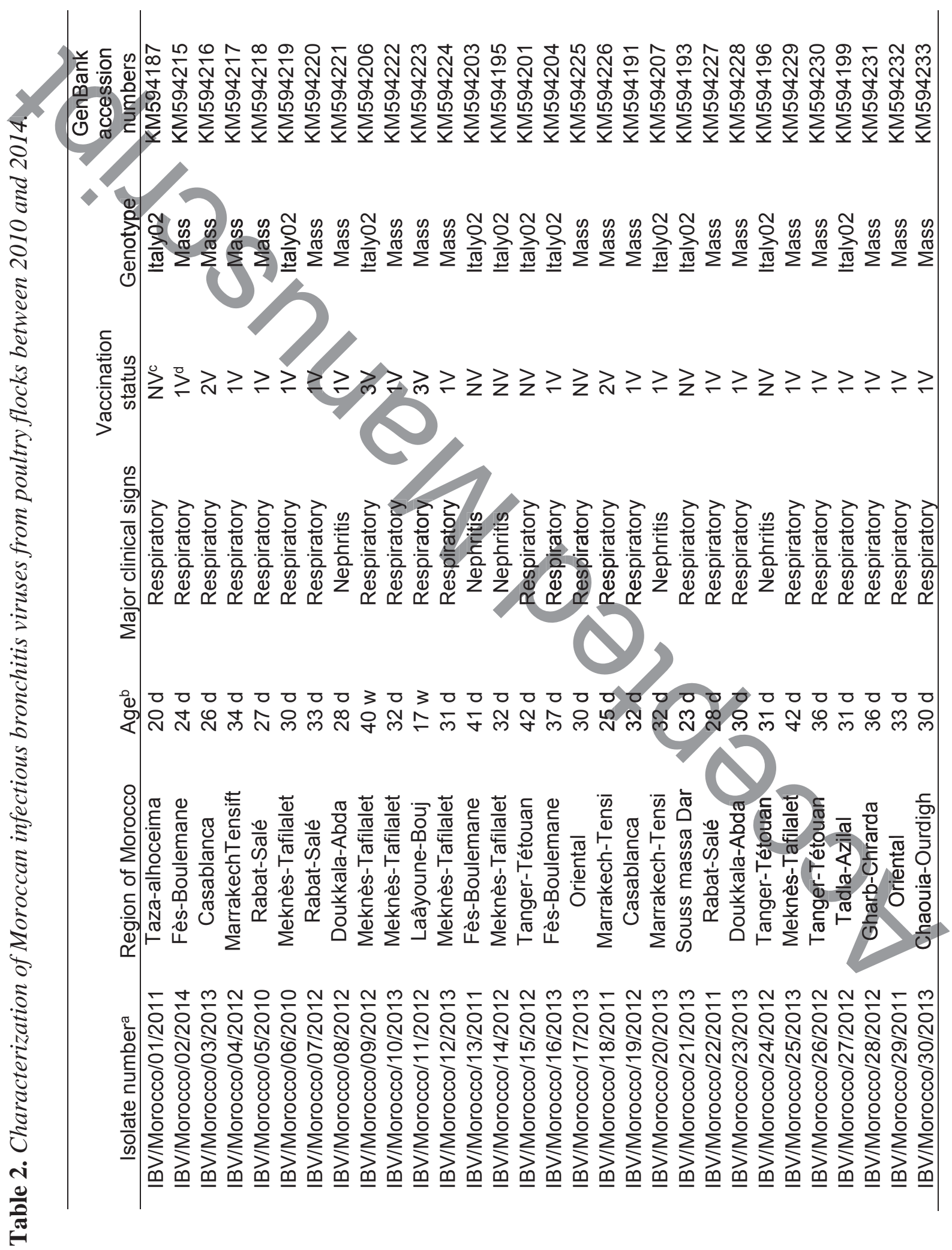

Comment citer ce document 


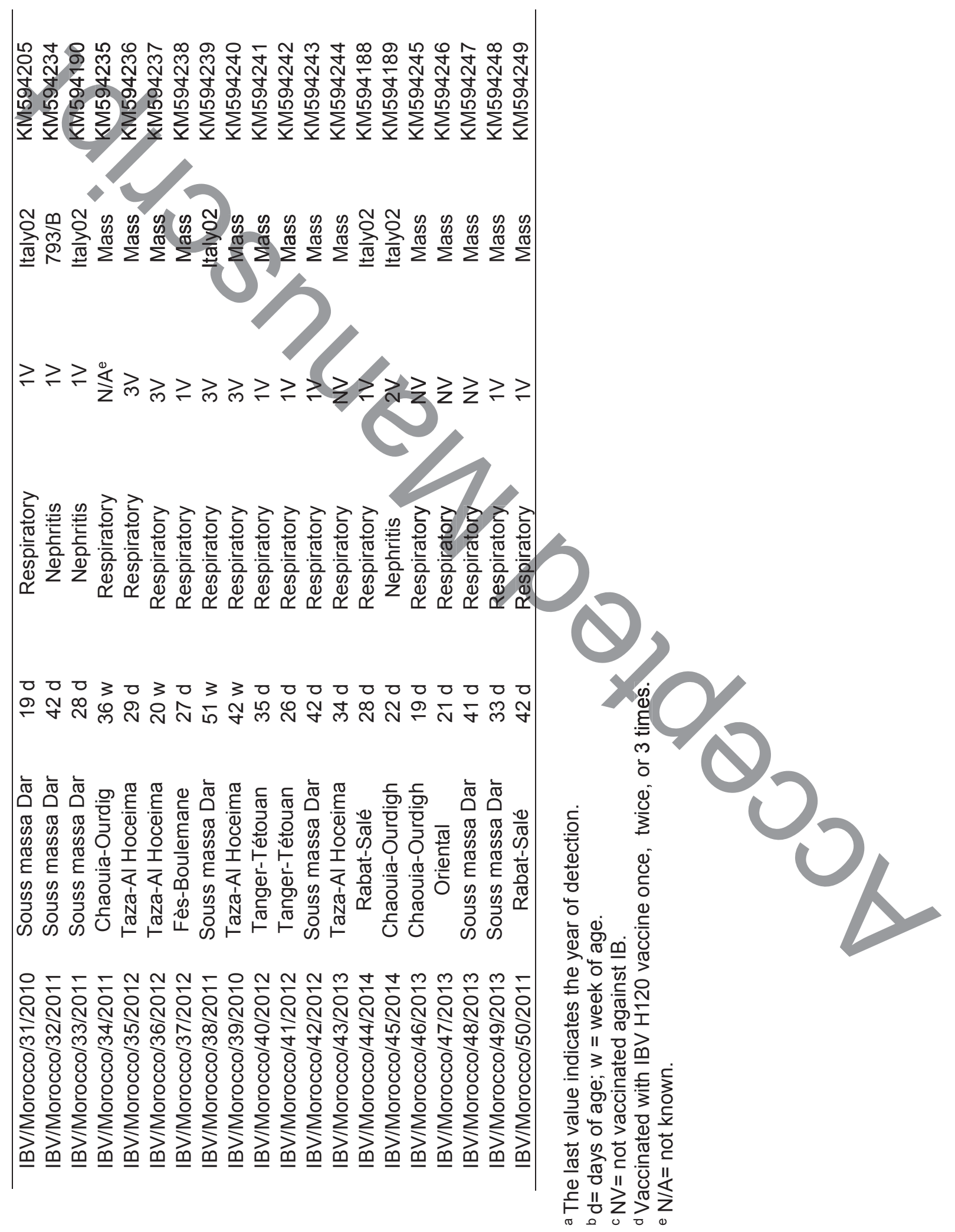

Comment citer ce document 